\title{
AN EXAMINATION OF THE ROLE OF COURTS IN ENSURING COMPLIANCE WITH THE CONSTITUTIONAL REQUIREMENTS FOR IMPEACHMENT IN NIGERIA
}

\author{
${ }^{1}$ Abdulahi Sani, ${ }^{2}$ Che Thalbi Md. Ismail \& \\ ${ }^{3}$ Aspalela A. Rahman \\ ${ }^{1,2,3}$ School of Law, College of Law,
} Government and International Studies, Universiti Utara Malaysia ${ }^{1}$ Faculty of Law, Bayero University, Kano Nigeria abuabdallah055@gmail.com;chet1048@uum.edu.my;
salbiismai161@gmail.com; lella@uum.edu.my

Received: 25 January 2018 Accepted: 8 July 2018 Published Online: 24 December 2018

\begin{abstract}
The constitution confers on the legislative arm of government impeachment power and prescribes when and how it should be exercised. Disputes arising from the exercise of this power are submitted to the courts for adjudication in line with their inherent powers. The issue of compliance with these constitutional requirements is a cause for concern as most of the impeachment proceedings conducted so far in Nigeria had been challenged in court for noncompliance. The question is, could this role played by the Nigerian courts ensure compliance? The objective of this paper is, therefore, to determine whether the courts could ensure compliance with the constitutional requirement for impeachment. In order to achieve the objective of this paper, doctrinal methodology is used whereby relevant materials were analyzed and conclusion made. The result showed that the role played by the courts cannot ensure compliance with the constitutional requirements because the courts only intervene after the conclusion of the exercise due to disrespect to court orders from the legislature. This is largely due to lack of specific role conferred on the courts in impeachment proceedings. It is, therefore, recommended that the constitution be amended to vest on the Supreme Court the specific role of ensuring
\end{abstract}


that all the constitutional requirements for impeachment have been duly complied with before a public officer is removed.

Keywords: Islamic Law, Malaysian Law, Environmental Conservation, Water Pollution.

\section{INTRODUCTION}

The Nigerian constitution vests on the legislature some powers under the constitutional democracy it operates. One of such powers is impeachment ${ }^{1}$ which, in a simpler way, is the act by the legislature calling for the removal of public officials which is accomplished by presenting a written charge of the official's alleged misconduct. ${ }^{2}$ The constitution also makes provisions on when and how the power is to be exercised ${ }^{3}$ failing which the exercise becomes null and void $^{4}$ because impeachment is considered as a serious business. ${ }^{5}$ Impeachment in Nigeria, like in other jurisdictions across the globe, is a constitutional requirement. Therefore, the constitution makes an elaborate provision on its requirements which the legislature is expected to strictly comply with in the course of its exercise. The constitution also makes provisions for the subjects of impeachment; who initiates it and how; the manner and the grounds upon which it is to be conducted and by whom. All these are requirements of the constitution which must be strictly observed for impeachment to be legal. Any infraction, breach or violation of these constitutional requirements is not only frowned at but also results in voiding the entire exercise. This is in line with the legal principle on the legal position of an act which is void as enunciated by the legendary Lord

1 The legislature at the federal level has the power to impeach the President and the Vice President while the legislature at the state level are empowered to impeach the state Governor and the Deputy Governor. See sections 143 and 188 of the constitution and Attorney General of the Federation vs. Abubakar (2007) All FWLR 375, 407.

2 Garner Bryan, Black's Law Dictionary (St. Paul, Minn: West Publishing Co., 2009) 678.

3 See sections 143 and 188 of the constitution of the Federal Republic of Nigeria, 1999 (as amended).

4 Shikyl, S. 'Constitutional Designs and Justiciability of Impeachment under the 1999 Nigerian Constitution' (2007) 2 Nigerian Journal of Legislative Affairs, 28.

$5 \quad$ Inakoju v Adeleke (2007) NWLR 1 at 123 
Denning which is worth quoting here. He said in the celebrated case of Benjamin Leornard Macfoy vs. United Africa Company Ltd that:

...If an act is void, then it is in law a nullity. It is not only bad but incurably bad. There is no need for an order of court to set it aside. It is automatically null and void without more ado, though it is sometime convenient to have the court declare it to be so. And every proceeding which is founded on it is also bad and incurably bad. You cannot put something on nothing and expect it to stay there. It will collapse... ${ }^{6}$

In the light of the above judicial pronouncement, any impeachment built on illegality and noncompliance with constitutional requirements will surely collapse. This is because it has been the responsibility of the courts to ensure that the laid down provisions of the constitution have always been complied with. ${ }^{7}$ Therefore, the judiciary acts as a watchdog over the other organs of government and ensures their fidelity to supremacy of the Constitution. ${ }^{8}$ This makes it an essential organ which balances the exercise of powers in the political entity of any nation among its organs of the government. ${ }^{9}$ The question here is could the role played by courts ensure compliance with the constitutional requirements? Therefore, the objective is to determine whether the role played by courts is capable of ensuring compliance with the constitutional requirements for impeachment. Doctrinal methodology is used whereby materials relevant to the research were analyzed in order to achieve the stated objective.

6 Benjamin Leornard Macfoy v United Africa Company Ltd. (1962) AC 150 at 160.

7 I.T. Mohammad (2012) "Judicialism and Electoral Processes in Nigeria: What the Supreme Court Did; What the Supreme Court May Do", being a paper presented at the 2012 Felix Okoye Memorial Lecture, Organized by Nigerian Institute of Advanced Legal Studies, University of Lagos, held at the Nigerian Institute of Advanced Legal Studies, University of Lagos, on 18th September 2012.

8 Imo John 'The Power of Judicial Review in the Promotion of Constitutionalism in Nigeria: Challenges and Prospects' (2015) 40 Journal of Law, Policy and Globalization, 192-205.

9 Egbewole Wahab 'Nigerian Judiciary and Consolidation of Democracy: Analysis of Election Petitions' in Olarinde O. N and Wale Akinlabi Jr. (eds), Essays and Selected Judgment in Honour of an Incorruptible Judge, Hon. Justice John Olagoke Ige , (Ibadan: Crown Goldmine Communication Ltd, 2008) 67. 


\section{IMPEACHMENT AS MECHANISM FOR CHECKS AND BALANCES}

First and foremost, impeachment is intended to function as an instrument to check the excesses of the executive and in some dominions even the judicial arm of government ${ }^{10}$. This is on the basis of the principle of separation of powers which defends the society from impunity by any arm of government and makes certain that each arm preserves its own sphere of influence. ${ }^{11}$ So, the judiciary checks the exercise of powers by both the executive and the legislature by way of judicial review to guarantee that they function within their scopes as provided by the constitution. ${ }^{12}$ The executive, on the other hand, exercises some level of power over the judiciary in terms of appointment and discipline and over the legislature in cases of endorsement of legislations ${ }^{13}$ and fiscal expenditure. The legislature also checks the judiciary in terms of endorsement of their appointment and financial expenditure ${ }^{14}$ while the executive is exposed to the control of the legislative assembly in cases of some appointments, expenditure and impeachment for misconduct. Therefore, impeachment is machinery meant to check the excesses in the exercise of the executive powers. ${ }^{15}$

Having checked the excesses of the office holders as discussed above, impeachment additionally affords an opportunity to hold them responsible for the misconducts they committed while in office. In many jurisdictions that practice democracy across the globe, the President, Vice President and other members of the executive at the various levels of government enjoy legal protection from suits for their acts or omissions during the period they occupy the particular offices. This makes all their actions and omissions immune from accountability which is a cardinal element in governance. In Nigeria,

10 Section 6 (6) of the Constitution of Nigeria; Adesanya v President of Nigeria (1982) 2 NCLR 356.

11 Obiora Chukura and Chukwuemeka, Melachy 'Constitutionalism, Impeachment and Democracy in Nigeria: An Appraisal' (2012) 12 Journal of Constitutional Development, 44-45.

12 See section 6 of the Constitution of Nigeria.

13 National Assembly v The President of Federal Republic of Nigeria (2003) 41 WRN 94; Mowoe Kehinde Constitutional Law in Nigeria, (Lagos: Mathouse Press Ltd.,2008) 26.

14 Sections 80-84 of the constitution of Nigeria.

15 Mowoe, Constitutional Law in Nigeria, op cit. 26. 
for instance, the President, Vice President, Governor and Deputy Governor enjoy such legal protection. The constitution provides thus:

1. Notwithstanding anything to the contrary in this Constitution, but subject to subsection (2) of this section-

a. no civil or criminal proceedings shall be instituted or continued against a person to whom this section applies during his period of office;

b. a person to whom this section applies shall not be arrested or imprisoned during that period either in pursuance of the process of any court or otherwise; and

c. no process of any court requiring or compelling the appearance of a person to whom this section applies, shall be applied for or issued:

Provided that in ascertaining whether any period of limitation has expired for the purposes of any proceedings against a person to whom this section applies, no account shall be taken of his period of office.

2. The provisions of subsection (1) of this section shall not apply to civil proceedings against a person to whom this section applies in his official capacity or to civil or criminal proceedings in which such a person is only a nominal party.

3. This section applies to a person holding the office of President or Vice-President, Governor or Deputy Governor; and the reference in this section to "period of office" is a reference to the period during which the person holding such office is required to perform the functions of the office. ${ }^{16}$

This is immunity from legal proceedings which elected executive office holders who may be subjected to impeachment enjoy while in office. ${ }^{17}$ Therefore, impeachment presents itself as the only way to

See section 308 of the constitution of Nigeria.

17 The concept of Immunity under the Nigerian constitution had received so much judicial interpretation in a lot of pronouncements from the Nigerian superior courts. See for instance the cases of Tinubu v I.M.B. Securities Plc (2001) All FWLR (pt.77) 1003; Alameyeseigha v Yeiwa (2002) All FWLR (t. 96) 552; Media Tech Nig. Ltd., v Lam Adesina (2005) 1 (t. 908) 461; I C S Nig. Ltd. v Balton B. V.(2003) 8 NWLR (t. 822) 223; Umnah v Attah (2004) 7 (t. 871) 63; Alameiyeseigha v Federal Republic of Nigeria (2006) 16 (t. 1004) 1; Gani Fawehinmi v Inspector General of Police (2002) All FWLR (t. 108); Global Excellence Communication Ltd. v Mr Donald Duke (2007) 16 NWLR (t. 1059) 22. 
call elected executives to account for their wrongdoings in Nigeria during the pendency of their offices.

\section{OUTLINE OF THE CONSTITUTIONAL REQUIREMENTS FOR IMPEACHMENT}

The constitution makes elaborate provision on the grounds and the procedure for impeachment. For instance, section 188 provides:

(1) The Governor or Deputy Governor may be removed from office in accordance with the provisions of this section.

(2) Whenever a notice of allegation in writing signed by not less than one-third of the members of the House of Assembly-

(a) is presented to the speaker of the House of Assembly of the state;

(b)stating that the holder of such office is guilty of gross misconduct in the performance of the functions of his office, details particulars of which shall be specified, the Speaker of the House of Assembly shall, within seven days of the receipt of the notice, cause a copy of the notice to be served on the holder of the office and on each member of the House of Assembly, and shall also cause any statement made in reply to the allegation by the holder of the office, to be served on each member of the House of Assembly.

(3) within fourteen days of the presentation of the notice to the Speaker of the House of Assembly (whether or not any statement was made by the holder of the office in reply to the allegation contained in the notice), the House of Assembly shall resolve by motion, without any debate whether or not the allegation shall be investigated.

(4) A motion of the House of Assembly that the allegation be investigated shall not be declared as having been passed unless it is supported by the votes of not less than two-third majority of all the members of the Hose of Assembly.

(5) within seven days of the passing of the motion under the foregoing provisions of this section, the Chief judge of the state shall, at the request of the speaker of the House of Assembly, appoint a panel of seven persons who in his opinion are of unquestionable integrity, not being members of any public 
service, legislative house or political party, to investigate the allegation as provided in this section.

(6) The holder of an office whose conduct is being investigated under this section shall have the right to defend himself in person or be represented before the panel by a legal practitioner of his own choice.

(7) A panel appointed under this section shall

(a) have such powers and exercise its functions in accordance with such procedure as may be prescribed by the House of Assembly; and

(b) within three months of its appointment, report its findings to the House of Assembly.

(8) Where the panel reports to the House of assembly that the allegation has not been proved, no further proceedings shall be taken in respect of the matter.

(9) where the report of the panel is that the allegation against the holder has been proved, then within fourteen days of the receipt of the report, the House of assembly shall consider the report, and if by the resolution of the House of Assembly supported by not less than two-thirds majority of all its members, the report of the panel is adopted, then the holder of the office shall stand removed from office as from the date of the adoption of the report.

(10) No proceedings or determination of the panel or of the House of Assembly or any matter relating to such proceedings or determination shall be entertained or questioned in any court.

(11) In this section

"gross misconduct" means a grave violation or breach of the provisions of the constitution or a misconduct of such a nature as amounts in the opinion of the house of Assembly to gross misconduct. ${ }^{18}$

Thus, in view of the above constitutional provisions, the requirement for impeachment is both substantive and procedural. As for the substantive requirements, the impeachment power could only be exercised on the grounds that the office holder has committed gross misconduct in the exercise of his official responsibility. The existence

18 Similar provisions apply in the case of the President and Vice President mutati mutandis (with some necessary changes). See section 143 of the constitution. 
of those grounds is what actually triggers the commencement of impeachment proceedings. Furthermore, it is the proof of those grounds that gives rise to successful result of impeachment which culminates in the removal of the public officer involved. Thus, the ground for impeachment under the Nigerian constitution is gross misconduct. ${ }^{19}$ Gross misconduct, as provided under the constitution, means grave violation of the constitution or any misconduct considered by the legislature to be gross misconduct. ${ }^{20}$ Based on this, there are two categories of misconducts for the purpose of impeachment. They are grave violation of the constitution and any misconduct which the legislature considers as gross misconduct. For the first category, so many violations of the constitution were considered as gross misconducts sufficient to justify impeachment. Therefore, in an attempt to provide an insight into the nature of constitutional breaches that could justify impeachment, the Supreme Court recognized the following violations. The court said:

The following, in my view, constitute grave violation or breach of the Constitution: (a) Interference with the constitutional functions of the Legislature and the judiciary by an exhibition of overt unconstitutional executive power, (b) Abuse of the fiscal provisions of the Constitution, (c) Abuse of the Code of Conduct for Public Officers (d) Disregard and breach of Chapter IV of the Constitution on fundamental rights, (e) Interference with Local Government funds and stealing from the funds or pilfering of the funds including monthly subventions for personal gains or for the comfort and advantage of the State Government, (f) Instigation of military rule and military government, (g) Any other subversive conduct which is directly or

19 The President, Vice President, Governor or Deputy Governor may be removed from office on the ground that he was found guilty of gross misconduct. See section 143 (2) (b) and 188 (2) (b) of the constitution.

20 See sections 143 (10) and 188 (10) of the constitution of Nigeria. The Supreme Court provided an insight into what could mean gross. The court, per Niki Tobi JSC said: The word "gross" in section 188(11) of the 1999 Constitution means generally in the context atrocious, colossal, deplorable, disgusting, dreadful, enormous, gigantic, grave, heinous, outrageous, odious and shocking. Inakoju v Adeleke (2007) LPELR 10354. 
indirectly inimical to the implementation of some other major sectors of the Constitution. ${ }^{21}$

These are some of the constitutional violations that could warrant impeachment under the Nigerian constitution as opined by the learned justice of the Supreme Court of Nigeria. Although this may not be the law, since it is a mere expression of opinion, but it could go a long way in guiding the lawmakers in the determination of what constitutes violation of the constitution as a ground for impeachment.

The other aspect of gross misconduct under the constitution as a ground of impeachment is that whatever the legislature consider as gross misconduct. This is very nebulous provision in that the legislature has the discretion to term whatever conduct as gross. However, the learned justice of the Supreme Court gave an opinion as to guide the legislature on what may be regarded as gross misconduct for the purpose of impeachment. These misconducts include refusal to perform constitutional function, corruption, sexual harassment, certificate forgery and drunkenness. ${ }^{22}$

As for the procedural requirements of impeachment, three main stages are involved. First is the presentation of the notice of allegation of gross misconduct to the substantive or acting Speaker of the House of Assembly in case of the impeachment of the Governor or Deputy Governor. In case of the impeachment of the President or Vice President, such notice is to be presented to the substantive or acting President of the Senate. The substantive or acting Speaker or President of the Senate shall serve it, within seven days of its receipt, on all members of the Assembly and the office holder to be subjected to the impeachment. ${ }^{23}$ This affords the members of the Assembly especially who were not part of the preparation of the allegations the opportunity to know the gross misconduct alleged. The object of the service of this notice is also to give information on the case against the Governor or Deputy Governor, as the case may be, and enable him to start preparation for his defense. ${ }^{24}$ This is why

$21 \quad$ Inakoju vs Adeleke (2007) LPELR 10354.

22 Ibid.

23 Same applies where the President or Vice President is the subject of the impeachment.

24 Mbenwulu v Olumba (2017) 5 NWLR (t. 1558) 169 SC. 
he is required to be served the notice personally. ${ }^{25}$ After the service, the members of the Assembly are required to pass a resolution, by the two-third majority votes of the total number of the members of the Assembly on whether to investigate the allegations.

The next stage is the appointment of the investigation panel. In case of the impeachment of President or Vice President, the constitution requires that the Senate President should request the Chief Justice of Nigeria to appoint the impeachment panel. In the impeachment of the Governor or Deputy Governor of a state, the Speaker of the House of Assembly concerned, on the other hand, is required to request the Chief Judge of the state to set up such panel. ${ }^{26}$ Such appointment should be made within seven days of the receipt of the request in that regards. It follows, therefrom, that no any member of the Assembly other than the Speaker, or the Senate President, could perform the function of requesting the Chief Judge or Chief Justice of Nigeria to appoint the impeachment panel. ${ }^{27}$ For the Chief Judge to qualify to perform this job, he should be one who is lawfully appointed as such either in a substantive or acting capacity. However, a substantive or acting Chief Judge who has been illegally appointed in that capacity cannot so act. $^{28}$

The last stage is that impeachment panel is required to prepare and submit to the Speaker of the House of Assembly or the Senate President the report of its findings within three months. Although there is no particular format prescribed for the report, but the constitution says that it should state whether the allegations of the gross misconduct as the grounds of impeachment labeled against the Governor or Deputy Governor have been proved or not. The report should not be interim but final of the findings of the impeachment panel. This means it should be one prepared after the final proceedings of the impeachment panel. ${ }^{29}$ Where the allegations have not been proved, that ends the procedure and the matter at all. This means that no any impeachment proceedings could again be instituted against the

\footnotetext{
25 See the cases of Nyako v Adamawa State House of Assembly (2017) 6 NWLR (pt. 1560) 347-424.

26 See section 188 (5) of the constitution of Nigeria

27 Hon. Micheal Dapialong \& Ors v Chief Joshua Dariye \& Ors (2007) NWLR

28 See the case of All Progressive Congress v Peoples Democratic Party (2015) 15 NWLR (pt. 1581) 1-204.

29 Sani Abubakar Danladi v Nasiru Audu Dangiri (2015)2 NWLR (pt. 1442) 124.
} 
same President or Vice President and Governor or Deputy Governor in respect of the same allegations of gross misconduct. Thus, the constitution says: "Where the Panel reports to each House of the National Assembly that the allegation has not been proved, no further proceedings shall be taken in respect of the matter. ${ }^{30}$ But this does not mean no more impeachment proceedings could again be instituted against the same President or Vice President and Governor or Deputy Governor before the end of his/her tenure. He/she could still be subjected to impeachment when there are fresh allegations of gross misconduct against him/her. However, where the report of the panel is that the allegations of gross misconduct against the President or Vice President and the Governor or Deputy Governor have been proved, then such report is subject to the discretion of the members of the National Assembly or House of Assembly to adopt or refuse to adopt. The constitution makes provision for numerical strength of the members eligible to adopt or endorse or approve the report of the impeachment panel. In this regards, the constitution says in respect of the Governor and Deputy Governor:

Where the report of the Panel is that the allegation against the holder of the office has been proved, then within fourteen days of the receipt of the report, the House of Assembly shall consider the report, and if by a resolution of the House of Assembly supported by not less than two-thirds majority of all its members, the report of the Panel is adopted, then the holder of the office shall stand removed from office as from the date of the adoption of the report. ${ }^{31}$

The requirement is that two-third of the total number of the members of the House of Assembly is to adopt the report of the impeachment panel which shows that the allegations of gross misconduct against the President or Vice President and Governor or Deputy Governor have been proved. The question here is does the two-third include members who are suspended or who are unavoidably absent at the House of Assembly session for the purpose of the impeachment?

30 Section 143 (8) of the constitution of Nigeria. A similar provision could also be found in section 188 (8) of the constitution. See also the case of All Progressive Congress v Peoples Democratic Party (2015) 15 NWLR (pt. 1581) 1-204.

31 See section 188 (9) of the constitution of Nigeria. 
The judicial interpretation given to this requirement is that two-third of all members of the House of Assembly including those who are absent during the plenary session and those suspended or no longer eligible to participate in the activities of the House of Assembly for some justifiable reasons. ${ }^{32}$ It follows, therefrom, that no any advantage could be derived from the manipulation of the required number of the members through unlawful suspension of members who are opposed to impeachment moves. Where the report of the impeachment panel is adopted by the required two-third of the total number of the members of the House of Assembly, the Governor or Deputy Governor becomes removed from the date of its adoption.

\section{NATURE OF COMPLIANCE WITH CONSTITUTIONAL REQUIREMENTS FOR IMPEACHMENT}

The exercise of impeachment power by the Nigerian legislature is a cause for concern as it leaves much to be desired..$^{33}$ Common problem to most cases of impeachment in Nigeria is noncompliance with the constitutional requirements ${ }^{34}$ which is becoming a recurring decimal $^{35}$ and which draws the concern of well-meaning Nigerians, lawyers and laymen alike. ${ }^{36}$ In fact, the way the Nigerian legislature conducts impeachment proceedings is unbecoming, unfortunate and embarrassing, to say the least. This is despite the fact that the legislature is not left without any form of guidance in the exercise of this important power as shown earlier. Therefore, any failure to strictly observe these provisions will invariably render the exercise futile. This is more so as the compliance is expected from the legislative arm of the government which is regarded as the custodian of the constitution. Thus, reiterating the importance of compliance with the constitutional requirements by the legislature in

See Dapialong v Dariye (2007) LPELR-SC.39/2007 and Adeleke v Oyo state House of Assembly (2006) 16 NWLR (pt.1006) 608 C.A.

33 Olafunmilayo Olopade, 'The Gale of Impeachments in Nigeria: A Threat to Sustainable Democracy', in Cross-cutting Issues in Nigerian Law: Essays in Honour of Funsho Adaramola, (Jamex Press, Lagos, 2009) 23.

34 Shikyl, op. cit. 1.

35 Lawal Mamman 'Abuse of Powers of Impeachment in Nigeria' (2010) 48 Journal of Modern African Studies, 314.

36 Akeredolu Ale The Supreme Court on Impeachment Proceedings, (St. Paul Publishing House, Ibadan, 2007) 2. 
the exercise of their powers including impeachment power and the likely consequences of failure to comply with the constitution in this direction, the Supreme Court said:

The Legislature is the custodian of a country's Constitution in the same way that the Executive is the custodian of the policy of Government and its execution, and also in the same way that the Judiciary is the custodian of the construction or interpretation of the Constitution. One major role of a custodian is to keep under lock and key the property under him so that it is not desecrated or abused. The legislature is expected to pet the provisions of the constitutions like the way the mother pet her day old baby. The legislature is expected to abide by the provision of the constitution like the way the clergyman abide by the bible and the imam abide by the Koran. Also, when the legislature, the custodian, is responsible for the desecration and abuse of the provision of the constitution in terms of patent violation and breach, society and its people are the victim and the sufferers... ${ }^{37}$

The exercise is also sometimes fraught with crises that result in physical combat among the lawmakers. ${ }^{38}$ As a result, impeachment is considered as one of the most troubling phenomenon ${ }^{39}$ and engaging issue in the Nigerian constitutional history. ${ }^{40}$ Besides this, the exercise is also becoming so frequent that there is no state in Nigeria which has not experienced the threat, attempt or actual impeachment of Governor or Deputy Governor in Nigeria ${ }^{41}$ which

37 Niki Tobi JSC in Inakoju v Adeleke (supra) 123

38 Egobueze, Ana 'Crisis and Crisis Management in the Legislature: The Rivers State House of Assembly Experience, 2011-2015' (2015) 26 Scottish Journal of Arts, Social Sciences and Scientific Studies, 1; Olasupo Fatai 'Impeachment at the State Level in Nigeria: Osun State as a Case Studies' (2015) 6 Beijing Law Review, 34.

39 Incessant impeachment a blot on Nigeria's democracy, Osun Defender, an online Nigerian newspaper, available at www.osundefenders.org accessed on $11 / 10 / 2016$

40 Jide, Olakanmi 'Evaluation of Impeachment Proceedings under the Constitution of the Federal Republic of Nigeria, 1999' Journal of Law, Policy and Globalization, (2015) 34.

41 Oni Micheal Abioudun 'Judicial Review of Governors Ladoja and Obi's Impeachment in Nigeria's Fourth Republic' (2013) 1 Singaporean Journal of Business Economics and Management Studies, 23. 
is unparalleled in the history of any constitutional democracy. ${ }^{42}$ This makes a prominent law lord of the Nigerian Supreme Court, Niki Tobi JSC, to capture the situation in the following words:

The plethora of removal proceedings in respect of Governors is not only frightening but is capable of affecting the stability of Nigeria. It is almost like a child's play as some State Legislatures indulge in it with all the ease and comfort like the way the English man sips his coffee on his breakfast table. Unless the situation is arrested, Nigerians will wake up one morning and look for where their country is. That should worry every good Nigerian. It does not only worry me; the idea frightens me so much. ${ }^{43}$

The result is that the exercise of impeachment powers by the Nigerian legislature is also mostly characterized by procedural irregularities. Evident to this is the fact that more than 90 per cent of the impeachment cases in Nigeria have been challenged in courts for procedural irregularities. In fact, there is so far no impeachment proceeding in which the issue of compliance with the constitutional requirements was not raised in Nigeria. In this light, it could be stated boldly that there is no constitutional requirement which had not been challenged for lack of compliance in court. In some cases, they were successfully challenged while in others they were not. Suffice it to state that the areas in which common noncompliance had been established successfully in courts are the requirements for quorum; ${ }^{44}$ the place and time to conduct legislative business in respect of impeachment proceedings; ${ }^{45}$ notice of allegations of gross misconduct ${ }^{46}$ and fair hearing before the investigation panel. ${ }^{47}$

42 Oni Ebenezer Oluwofe 'The Challenges of Democratic Consolidation in Nigeria, 1999-2007' (2014) 5 International Journal of Politics and Good Governance, 21 .

43 Inakoju v Adeleke (supra) 120.

44 Dapialong v Dariye (2007) LPELR-SC.39/2007; Inakoju v Adeleke (supra).

45 Sani Abubakar Danladi v Nasiru Audu Dangiri (2015)2 NWLR (pt. 1442) 124; Dapialong v Dariye (2007) LPELR-SC.39/2007; Inakoju v Adeleke (supra).

46 Balonwu v Obi (2007) 5 NWLR (pt. 1028) 488 C.A.; Nyako v Adamawa State House of Assembly (2017) 6 NWLR (pt. 1560) 347-424.

47 Gadi v Male (2010) 7 NWLR (pt. 1193) 238; Sani Abubakar Danladi v Nasiru Audu Dangiri (2015)2 NWLR (pt. 1442) 124; Nyako v Adamawa State House of Assembly (2017) 6 NWLR (pt. 1560) 347-424. 


\section{THE ROLE OF COURTS IN ENSURING COMPLIANCE}

Under the Nigerian constitution, there are established regular and special courts. The regular courts are those conferred with jurisdiction to entertain cases and matters for the determination of any question as to the civil rights and obligations of persons, government and authority in Nigeria. ${ }^{48}$ The special courts, on the other hand, are courts established on temporary or permanent basis and vested with the jurisdiction to deal with specific matters. ${ }^{49}$ The role which the courts play in impeachment is not more than that of judicial review ${ }^{50}$ which comes after the exercise had been concluded. Thus, where a party is aggrieved with the way and manner impeachment proceedings have been conducted, he approaches the court for judicial review of the exercise. This is because adjudication on disputes between parties through the interpretation and application of the law is the major role of the judiciary. ${ }^{51}$ Therefore, disputes arising from the exercise of impeachment powers of the legislature are submitted

48 Section 6 (6) (b) Constitution of Nigeria. Such courts include superior courts like the Supreme Court, Court of Appeal, Federal High Court, High Courts of states and the Federal Capital Territory, Sharia Court of Appeal of the states and the Federal Capital Territory, Abuja, Customary Court of Appeal of states and that of the Federal Capital Territory, Abuja and lower courts.

49 The courts include Election Tribunals, Court Martial and Code of Conduct Tribunal. See sections 285 of the Constitution; fifth Schedule to the constitution, Code of Conduct Bureau and Tribunal Act, and Dr Bukola Saraki v Federal Government of Nigeria SC/852/2015, 5/2/2016; and section 143 of The Armed Forces Act, Cap A 20 Laws of the Federation of Nigeria, 2004, and Major Dennis v Nigerian Army (2015) LPELR 25969 (CA) respectively.

50 Judicial review has been described as the power of the court, in appropriate proceedings before it, to declare a legislative or executive act either contrary to, or in accordance with, the Constitution, with the effect of rendering the act invalid or vindicating its validity and so putting it beyond challenge in future. In other words, judicial review "entails judicial intervention in the exercise of powers by the other institutions of government and those who have been charged with the duties and authorities of those institutions..."

51 Dahiru Mustapher, (2011) The Nigerian Judiciary: Towards Reform of Bastion of Constitutional Democracy, Nigerian Institute of Advanced Legal Studies, Abuja, 7. Similarly, on the duty of the courts in relation to the interpretation of the law, Lord Denning once asserted that "the English Language is not an instrument of mathematical precision. Consequently, a judge should not be a mere mechanic in the power house of semantics. He should be the man in charge of it". See Lord Denning in Seaford Court Estates Limited v Asher (1949) 2 K.B. 481 at 489-499; Lord Denning, The Discipline of Law (London: Butterworth, 1979) 56-57. See also Brown v Allen, 344 U.S. 443, 540 (1953). 
to the regular courts for adjudication by the aggrieved party. ${ }^{52}$ By virtue of the provision of the constitution, which is the organic law in Nigeria, the judiciary has the prime duty to inquiry on whether the executive has acted intra vires or ultra vires or has conformed strictly to the procedure, mode or form set by law. ${ }^{53}$ The constitution also subjects the exercise of legislative power to the jurisdictions of court. ${ }^{54}$ By this provision, the official acts of the legislature could be subjected to judicial review by challenging its constitutionality before a competent court of law.

In view of the above, one of the earliest cases of impeachment submitted for judicial review was that of Alhaji Abdulkadir Balarabe Musa who was removed through impeachment as the first elected Governor of Kaduna state in 1981. The Governor had challenged, before the High Court of justice of Kaduna State and the Court of Appeal, various aspects of the procedure the Kaduna State House of Assembly followed in the impeachment. The courts declined to entertain his suits on the ground, among others, that impeachment proceedings were excluded from the jurisdictions of the court. This was premised on the ouster clause contained in the impeachment provisions under the then constitution. This decision served as the locus classicus as far as jurisdiction of the Nigerian courts in impeachment proceedings is concerned. This is because the decision was followed strictly by the High Court of Abia State and the Court of Appeal, Enugu division some twenty years later in Abaribe vs. Abia State House of Assembly. ${ }^{55}$

In 2007, there was a paradigm shift in this judicial attitude towards jurisdiction in impeachment proceedings. This was following the Supreme Court's liberal interpretation of the ouster clause ${ }^{56}$ contained

52 The Federal High Court and the High Court of states serve as courts of first instance in disputes arising out of impeachments pursuant to their inherent jurisdictions as provided under sections 251 and 272 of the constitution of Nigeria respectively.

53 Benjamin Ogwo "The Role of Law in Checkmating Executive Lawlessness in Nigeria from 1999-2014" (2015) 37 Journal of Law, Policy and Globalization, 217.

54 Section 4(8) of the constitution

55 (2002) 14 NWLR (pt.788) 466.

56 Many cases of impeachment were declined by the courts on the basis, among others, of the ouster clause. See for instance; Balarabe Musa v Auta Hamza \& Ors (1982) 3 NCLR 439; Abaribe v The Speaker, Abia State House of Assembly 
in the impeachment provisions under the constitution which hitherto served as one of the legal clogs in judicial intervention. ${ }^{57}$ Justifying the decision, the court in Inakoju vs. Adeleke ${ }^{58}$ declared that "where the constitution has made a provision as to any particular procedure or mode of exercising any legislative function, if there is breach of such provisions, the court will assume jurisdiction as the guardians of the constitution, to intervene and ensure compliance with the provision of the constitution". ${ }^{59}$ The duty of the court in this direction is to ensure that all the constitutional provisions regulating the exercise of the power of impeachment have been fully respected. Thus, the Supreme Court reiterated the role expected of the courts to perform in such cases when it stated:

Impeachment of elected officials is a very serious matter and should not be conducted as a matter of course. The purpose is to set aside the will of the electorates as expressed at the polls. It has implication for the impeached as well as the electorates who bestowed the mandates on him. Whether it takes one day or the three months prescribed by law, the rules of due process must be followed. If the matter is left at the whims and caprices of politicians and their panels, a state or even the entire country could be reduced to the status of a banana republic the procedure for impeachment and removal must be guarded jealously by the courts. ${ }^{60}$

Considering the implication of impeachment as pointed out in the above judicial pronouncement by the apex court, "...it must be strictly and duly observed so as not to thwart the will of the electorates

(2002) 14 NWLR (pt.788) 466. Some scholars also opined that the courts were skeptical to intervene due to the doctrine of political question and the need to maintain a delicate balance between the judicial role and the working of other branches of government. See for instance, Popoola Abiodun "The Courts and the Democratic Process in Nigeria: An Appraisal of the Application of Some American Judicial Doctrines", in Bello Ajibade (ed) Law, Democratic Governance and Justice Administration in Nigeria (Life Gate Publishing Co. Ltd., Ibadan, 2009) 275.

57 Inakoju vs. Adeleke (supra).

58 (supra)

59 Ibid, 144

60 Sani Abubakar Danladi v Nasiru Audu Dangiri (2015)2 NWLR (pt. 1442) 124 at 142 . 
freely expressed at the polls" ${ }^{61}{ }^{6}$ However, despite the judicial activism exhibited by the Supreme Court in the case of Inakoju vs. Adeleke ${ }^{62}$ which resulted in the paradigm shift in the attitude of Nigerian courts to judicial review of impeachment cases, much is left to be desired. This is because the courts could only entertain complaints on the procedure for the exercise of impeachment powers. They could not determine whether the allegations of misconduct against the public officer concerned are gross to justify impeachment. This is the exclusive preserve of the legislature as provided in the constitution. This only role which the regular courts play may not be adequate to ensure compliance in the impeachment power of the legislature whose conducts make them like an "unruly horse".

Furthermore, even the inadequate role of the regular courts by way of judicial review mostly comes at a time when the damage had already been done to the public officer who is the subject of the impeachment. This is because the courts have not been able to check the excesses of the legislature at the commencement or during the impeachment proceedings or so soon thereafter. In fact, it takes the courts between one and two years to finally dispose of impeachment disputes when the tenure of the public office holder subjected to the impeachment is about to end. In the worst cases, the impeachment proceedings which formed the basis of the removal were declared illegal and unconstitutional at the time when the tenure of the public officer had already expired! For instance, in the case of Nyako vs. Adamawa state House of Assembly, ${ }^{63}$ the impeachment of the Governor was finally affirmed as illegal and unconstitutional by the Supreme Court more than a year after the expiry of his tenure. Furthermore, the case of Danladi vs. Nasiru Abdu Dangiri ${ }^{64}$ is another impeachment case that readily comes to mind. The appellant, Sani Abubakar Danladi, was removed by impeachment as the Deputy Governor of Taraba State by the Taraba State House of Assembly on $4^{\text {th }}$ October, 2012 but the impeachment was finally declared illegal and unconstitutional on $21^{\text {st }}$ November, 2014, after a period of more than two years and barely six months to the end of his four-year term of office. So many instances abound which expose the inadequacy of the regular court

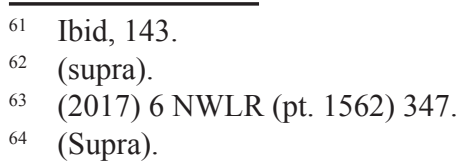


in ensuring compliance with the constitutional requirements for impeachment.

In most of these cases, the parties resorted to judicial review of impeachment because the courts were rendered virtually handicapped to ensure compliance during the pendency of the impeachment proceedings because courts' intervention by way of order were not respected as such the lawmakers went ahead with the impeachment in the face of apparent noncompliance with the requirements. Thus, most efforts by the courts to ensure that there is compliance during the exercise of impeachment power had been thwarted by not respecting court orders giving directions as to what and how to go about it. Court orders once given must be respected otherwise the authority and administration of the court will be brought into disrepute, scorn or disrespect. ${ }^{65}$ In the same vein, "The court is gradually beginning to lose its integrity as a result of flagrant disregard of its orders and judgments especially from other arms..." ${ }^{166}$ Consequently, the court will be rendered helpless as no sufficient remedy could be granted to the other party thereby reducing it to a toothless bull dog that can only bark but cannot bite. ${ }^{67}$ So many cases abound which expose the inadequacy of the role of the courts to ensure compliance with constitutional requirements for impeachment due to lack of respect for court order in impeachment proceedings. For, instance, the court order issued during the impeachment of Murtala Nyako as the Governor of Adamawa state that he be personally served with the impeachment notice as required by the constitution was flagrantly not complied with. In fact, the House of Assembly not only refused to comply but its Speaker justified the refusal in his words:

The issue of impeachment is constitutional responsibility of the lawmakers and the House of Assembly will not allow the judiciary to intervene in it because there is no going back over the impeachment exercise which the court lack the constitutional power to intervene. ${ }^{68}$

\footnotetext{
$65 \quad$ Ibhade Nigeria Ltd v Akware (2015) 13 NWLR (1477) 507.

66 Onyesi chukwudi kingsley "Knitting Contempt of the Law to the Administration of Justice in Nigeria: No Longer at Ease", available at https//:www.researchgate. net/publication/317640076 (accessed on 12 August, 2017).

67 Danladi vs. Dangiri (supra).

68 "Nyako: No court can Stop us- Adamawa law makers", African Spotlight Newspaper, June 30, 2014, available at africanspotlight.com (accessed on February 12, 2017).
} 
Similar scenarios played out in the impeachment of Garba Gadi, Deputy Governor of Bauchi State; ${ }^{69}$ impeachment of Rasheed Ladoja, Governor of Oyo State $;^{70}$ impeachment of Peter Obi, Governor of Anambra State ${ }^{71}$ and that of Joshua Dariye, Governor of Plateau State. ${ }^{72}$ In all these cases impeachments were conducted in defiance to an issued or anticipated court order. Consequently, the courts were rendered helpless as such they had to wait until after the exercise had been concluded before they could review compliance or otherwise.

\section{CONCLUSION}

In the light of the preceding discussions, it is found that the role played by the courts is grossly inadequate and cannot ensure compliance with the constitutional requirements for impeachment. This is because no any specific role is conferred on the courts apart from the general and inherent role of judicial review of impeachment which only comes after the exercise had been concluded. This is a serious limitation which exposes the inadequacy of the courts to ensure compliance. It is recommended that sections 143 and 188 of the constitution be amended to confer specific role on the Supreme Court to ensure that all the constitutional requirements for impeachment have been duly complied with by the legislature before a public officer is removed through impeachment. The requirements under some constitutions across the globe is that a Constitutional Court, Supreme Court or any other special court or tribunal is saddled with the role of ensuring compliance by the legislature. Thus, this is the requirement under the constitutions of countries such as South

\footnotetext{
69 Gadi v Male (2010) 7 NWLR (pt. 1193) 238.

70 Inakoju v Adeleke (2007) LPELR 10354.

71 Balonwu v Obi (2007) 5 NWLR (pt. 1028) 488 C.A. Dapialong v Dariye (2007) LPELR-SC.39/2007.

72 Dapialong v Dariye (2007) LPELR-SC.39/2007.
} 
Korea, ${ }^{73}$ Uganda,${ }^{74}$ Trinidad and Tobago, ${ }^{75}$ Sri Lanka,${ }^{76}$ South Sudan, ${ }^{77}$ Somalia, ${ }^{78}$ Slovenia, ${ }^{79}$ Singapore, ${ }^{80}$ Sierra Leone, ${ }^{81}$ Seychelles, ${ }^{82}$ Rwanda, ${ }^{83}$ Russian Federation, ${ }^{84}$ Romania, ${ }^{85}$ Angola, ${ }^{86}$ Armenia, ${ }^{87}$ Guyana, ${ }^{88}$ Croatia,${ }^{89}$ Cyprus, ${ }^{90}$ Dominica, ${ }^{91}$ East Timor, ${ }^{92}$ Egypt,${ }^{93}$ the Gambia, ${ }^{94}$ Germany, ${ }^{95}$ Hungary, ${ }^{96}$ Indonesia, ${ }^{97}$ Kazakhstan,,${ }^{98}$ Kosovo, ${ }^{99}$ Madagascar, ${ }^{100}$ Mauritius ${ }^{101}$ and Moldova. ${ }^{102}$

73 Article 65 of the constitution of the Republic of South Korea; Soon-yang Kim, 'The Veto Point Politics of the Presidential Impeachment in South Korea' (2012) 39 The Korean Social Science Journal, 35; Justin Mccurry (2017) "Park Geunhye: South Korean Court removes President over Scandal”, The Guardian, March 10, 2017 available at https://www.theguardian.com/world/2017/mar/10/ south-korea-president-park-geun-hye-constitutional-court-impeachment (accessed on March 1, 2018. Matt Stiles (2017) "South Korea's president is removed from office as court upholds her impeachment", Los Angeles Times, March 9, 2017, available at http://www.latimes.com/world/asia/la-fg-southkorea-park-impeach-2017-story.html (accessed on February 2, 2018). Article 107 of the constitution of Uganda, 2010.

section 36 of the constitution of Trinidad and Tobago, 1976.

Article 38 of the constitution of Sri Lanka, 1978.

Article 103 of the constitution of South Sudan, 2011.

Article 92 of the constitution of Somalia, 2012.

Article 109 of the constitution of Slovenia, 1991.

Article 22 of the constitution of Singapore, 1963.

Section 51 of the constitution of Sierra Leon, 1991.

Article 53 of the constitution of Seychelles, 1993.

Article 105 of the constitution of Rwanda, 2003.

Article 93 of the constitution of Russian Federation, 1993.

Article 96 of the constitution of Romania, 1991.

Article 129 of the constitution of Angola, 2010.

Article 57 of the constitution of Armenia, 1995.

Article 180 of the constitution of Guyana, 1980.

Article 105 of the constitution of Croatia, 1992.

Article 45 of the constitution of Cyprus, 1960.

Section 25 of the constitution of Dominica, 1984.

Article 79 of the constitution of East Timor, 2002.

Article 159 of the constitution of Egypt, 2014.

Section 67 of the constitution of the Gambia, 1996.

Article 61 of the constitution of Germany, 1949.

Article 13 of the constitution of Hungary, 2011.

Article 7 of the constitution of Indonesia, 1949.

Article 47 of the constitution of Kazakhstan 1995.

Article 91 of the constitution of Kosovo, 2008.

Article 131 of the constitution of Madagascar, 2010.

section 30 of the constitution of Mauritius, 1968.

Article 89 of the constitution of Moldova, 1994. 


\section{REFERENCES}

"Nyako: No court can Stop us- Adamawa law makers", African Spotlight Newspaper, June 30, 2014, available at africanspotlight.com (accessed on February 12, 2017).

Akeredolu, A. (2007). The Supreme Court on Impeachment Proceedings. St. Paul's Publishing House, Ibadan, Nigeria.

Benjamin, O. (2015) .The Role of Law in Checkmating Executive Lawlessness in Nigeria from 1999-2014. Journal of Law, Policy and Globalization, 37, 217-220.

Dahiru, M. (2011). The Nigerian Judiciary: Towards Reform of Bastion of Constitutional Democracy, Nigerian Institute of Advanced Legal Studies, Abuja, 7

Egbewole, O. W. (2008). Nigerian Judiciary and Consolidation of Democracy: Analysis of Election Petitions. In Olarinde O. $\mathrm{N}$ and Wale A Jr. (eds), Essays and Selected Judgement in Honour of an Incorruptible Judge, Hon. Justice John Olagoke Ige ( p.67). Crown Goldmine Communication Ltd, Ibadan.

Egobueze, A. (2015). Crisis and Crisis Management in the Legislature: The Rivers State House of Assembly Experience, 2011-2015. Journal of Arts, Social Sciences and Scientific Studies, 1-19.

Garner, B. A., \& Black, H. C. (2009). Black's law dictionary. 9th ed. St. Paul, MN: West.

Muhammad, I. T. (2012 September). Judicialism and electoral processes in Nigeria: What the Supreme Court did; What the Supreme Court may do. Dr. Felix Okoye Memorial Lecture Series. Nigerian Institute of Advanced Legal Studies (NIALS). Abuja: NIALS Press.

Imo, J. (2015). The Power of Judicial Review in the Promotion of Constitutionalism in Nigeria: Challenges and Prospects 40. Journal of Lawz, Policy and Globalization, 192-205.

Incessant impeachment a blot on Nigeria's democracy, Osun Defender, an online Nigerian newspaper, available at www. osundefenders.org (accessed on 11/10/2017).

Jide, O. (2015). Evaluation of Impeachment Proceedings under the Constitution of the Federal Republic of Nigeria, 1999. Journal of Law, Policy and Globalization, 34-50.

Justin, M. (2017). Park Geun-hye: South Korean Court removes President over Scandal", The Guardian, March 10, 2017. Retrieved from https://www.theguardian.com/world/2017/ 
mar/10/south-korea-president-park-geun-hye-constitutionalcourt-impeachment (accessed on March 1, 2018).

Lawal, M. (2010). Abuse of Powers of Impeachment in Nigeria. Journal of Modern African Studies, 48, 314-318.

Lord, D. (1953). The Discipline of Law (London: Butterworth, 1979) 56-57. See also Brown v Allen, 344 U.S. 443, 540.

Matt, S. (2017). South Korea's president is removed from office as court upholds her impeachment, Los Angeles Times, March 9, 2017. Retrieved from http://www.latimes.com/world/asia/ la-fg-south-korea-park-impeach-2017-story.html (accessed on February 2, 2018).

Mowoe, K. (2008). Constitutional Law in Nigeria, (Lagos: Mathouse Press Ltd. 2008).

Obiora, C., \& Chukwuemeka, M. (2012). Constitutionalism, Impeachment and Democracy in Nigeria: An Appraisal. Journal of Constitutional Development, 12, 40-55.

Olafunmilayo, O. (2009). The Gale of Impeachments in Nigeria: A Threat to Sustainable Democracy, in Cross-cutting Issues in Nigerian Law: Essays in Honour of Funsho Adaramola, (Jamex Press, Lagos, 2009).

Olasupo, F. (2015). Impeachment at the State Level in Nigeria: Osun State as a Case Studies. Beijing Law Review, 6, 218-223.

Oni, E. O. (2014). The Challenges of Democratic Consolidation in Nigeria, 1999-2007. International Journal of Politics and Good Governance, 5, 17-29.

Oni, M. A. (2013). Judicial Review of Governors Ladoja and Obi's Impeachment in Nigeria's Fourth Republic. Singaporean Journal of Business Economics and Management Studies, 1, 23-43.

Onyesi, C. K. "Knitting Contempt of the Law to the Administration of Justice in Nigeria: No Longer at Ease", available at https//:www.researchgate.net/publication/317640076 (accessed on 12 August, 2017).

Popoola, A. "The Courts and the Democratic Process in Nigeria: An Appraisal of the Application of Some American Judicial Doctrines", in Bello Ajibade (ed) Law, Democratic Governance and Justice Administration in Nigeria (Life Gate Publishing Co. Ltd., Ibadan, 2009).

Shikyl, S. (2007). Constitutional Designs and Justiciability of Impeachment under the 1999 Nigerian Constitution. Nigerian Journal of Legislative Affairs, 2, 20-35. 
UUMJLS 10(1) Jan 2019 (1-24)

Soon-yang, K. (2012). The Veto Point Politics of the Presidential Impeachment in South Korea. The Korean Social Science Journal, 39, 30-49. 